\title{
PENGARUH BEBERAPA CARA KEMATIAN IKAN TERHADAP MUTU IKAN KAKAP (Lutjanus sp.)
}

\author{
Albert R. Reo \\ Staf Pengajar pada Program Studi Teknologi Hasil Perikanan, \\ Fakultas Perikanan dan IImu Kelautan UNSRAT, Manado, 95115.
}

ABSTRACT

The handling of fishery products play an important role in fisheries port production, which began from handling on board of fish caught on board, when land on the market, retailers get to the processing plant.

Storage temperature of fish plays an important role. The use of low temperatures around $0^{\circ} \mathrm{C}$ can extend the seizures (rigor mortis), lower enzymatic activity, bacterial, chemical and physical changes which naturn cap prolong the durability of the fish.

This study aims to determine the influence of the way, fish die on fish quality during cold storage.

Research results snapper fitness level based on the value- $K$ test is: $25.78 \%$ for injection/gancu, $48.99 \%$ for head treatment and the $50.34 \%$ for untreaded out of water dead.

Fish snapper (Lutjanus sp.) collected from fish farm on Likupang waters, the organoleptic and value-K is still suitable for consurmption and for processing raw materials.

Key words: rigor mortis, quality, snapper,(Lutjanus sp.).

\section{PENDAHULUAN}

Penanganan hasil perikanan berperan penting dalam memanfaatkan produksi perikanan. Perlakuan penanganan ikan dimulai sejak ikan ditangkap, di atas kapal, saat didaratkan, di pasar-pasar, pengeceran sampai ke pabrik pengolahan (Anonimous, 1992). Pada kenyataannya, penanganan hasil perikanan yang telah dianjurkan belum bisa menjamin mutu dari hasil tangkapan ikan.

Menurut Suwetja (1990), banyak faktor yang menentukan kecepatan penururan kesegaran ikan, diantaranya suhu penyimpanan. Suhu penyimpanan ikan memegang peranan penting pada saat ikan mati. Penggunaan suhu rendah sekitar $0^{\circ} \mathrm{C}$ setelah ikan mati dapat memperpanjang masa kejang (rigor mortis), menurunkan kegiatan enzimatis, bakterial, kimiawi dan perubahan fisik sehingga dapat memperpanjang daya awet ikan.

Cara kematian ikan pada saat penangkapan mempunyai pengaruh besar terhadap bermula dan berakhirnya rigor mortis yang berkonsentrasi terhadap mutu dan daya awet ikan. Kematian ikan melalui per- juangan yang hebat pada setiap teknis penangkapan, cara penanganan yang kasar mengakibatkan ikan luka, memperpendek daya awet dan menurunkan mutu. Di Indonesia usaha mempertahankan mutu produk ikan segar ini masih sering menjadi kendala utama dalam industri dan eksportireksportir hasil perikanan.

Untuk itu melalui penelitian ini penulis terdorong untuk mengadakan penelitian mengenai pengaruh cara kematian terhadap mutu ikan kakap selama penyimpanan dingin.

Dalam penelitian ini digunakan ikan kakap (Lutjanus sp.), karena ikan kakap memiliki daging putih yang banyak serta memiliki nilai ekonomis tinggi dan merupakan salah satu jenis ikan kualitas ekspor.

\section{METODOLOGI PENELITIAN}

\section{Bahan dan Alat}

Bahan baku yang digunakan dalam penelitain ini adalah ikan kakap, air suling bebas ion, aluminium foil, resin, glass wool, kertas lakmus, es, tissue rol, larutan $\mathrm{HclO}_{4}$ $10 \%$ dan $5 \%$, Iarutan $\mathrm{KOH} 10 \mathrm{M}$ dan $1 \mathrm{M}$, 
larutan $\mathrm{HClO}_{4} 5 \%$ dinetralkan dengan $\mathrm{KOH}$ $10 \mathrm{M}$ dan $1 \mathrm{M}$, larutan $\mathrm{NH}_{4} \mathrm{OH} 25 \%$, larutan $\mathrm{HCl} 1 \mathrm{M}$, larutan standar IMP dan Inosin, larutan pengelusi A $(0,002 \mathrm{M} \mathrm{HCl})$, dan larutan $\mathrm{B}(0,02 \mathrm{M} \mathrm{HCl}+0,6 \mathrm{M} \mathrm{NaCl})$.

Peralatan yang digunakan yaitu: cool box, gelas ukur, labu ukur, erlenmeyer, batang pengaduk, $\mathrm{pH}$ meter, gelas beker, centrifuse, timbangan analitik, mortar, pipet volumetrik, pipet tetes, magnetik stirer, kolom set, pisau, baki dan spektrofotometer.

\section{Tata Laksana Penelitian}

Sampel yang digunakan dalam penelitian ini adalah ikan kakap yang diambil di karamba perairan Likupang. Di tempat penangkapan diambil secara acak ikan kakap dengan ukuran $\pm 15-20 \mathrm{~cm}$, dimasukkan ke dalam plastik yang berisi gas $\mathrm{O}_{2}$ dan air laut dan dibawa ke laboratorium untuk ditempatkan pada akuarium. Setelah itu ikan dimatikan dengan 3 perlakuan yaitu: disuntik pada bagian otak ikan, dipukul dengan kayu pada bagian kepala dan dibiarkan mati menggelepar. Sampel ini dianalisis dengan 3 kali ulangan.

Sampel-sampel tersebut kemudian diambil untuk dianalisis dengan uji nilai-k di laboratorium. Kemudian sampel yáng lain disimpan dalam cool box yang berisi es kisaran $1-5^{\circ} \mathrm{C}$, dimana ikan dalam cool box berfungsi sebagai kontrol terhadap daya awet ikan selama penyimpanan dingin dengan pengamatan $0,2,4$ dan 6 hari.

\section{HASIL DAN PEMBAHASAN}

\section{Penilaian Organóleptik}

Dari hasil penilaian organoleptik ikan kakap segar yang disimpan dalam cool box pada suhu dingin, dengan perlakuan disuntik/gancu pada bagian otak, dipukul dengan kayu dan mati menggelepar, diperoleh nilai rata-rata organoleptik dengan 4 kali pengamatan dapat dilihat pada Tabel 1.

Berdasarkan Tabel 1, terlihat bahwa nilai organoleptik yang meliputi kesan umum ikan kakap segar yang berasal dari karamba (tempat pembudidayaan) di perairan Likupang, dalam 4 kali penilaian didapati adanya perbedaan nilai organoleptik pada setiap pengamatan, yaitu dengan nilai berkisar antara 4,8-50 dengan nilai rata- rata $50,45,7,38,5$ dan 26,2 untuk ikan yang diberi perlakuan disuntik $50,38,1,10$ dan 5,4 untuk ikan yang perlakuan dipukul dengan kayu; dan 50, 37,5, 9,5, 4,8 untuk ikan yang mati menggelepar.

Tabel 1. Data Hasil Analisa Organoleptik (Kesan Umum) Ikan Kakap (Lutjanus sp.) Segar dengan Penyimpanan Dingin dalam Cool Box

\begin{tabular}{|c|c|c|c|c|c|c|c|c|c|c|c|c|c|}
\hline \multirow{2}{*}{ Panelis } & \multicolumn{13}{|c|}{ Jumlah nilai kriteria untuk tiap pengamatan per 2 hari } \\
\hline & & Suntik $\frac{1}{2}$ & $\frac{g a n c u}{4}$ & 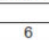 & 0 & & puku & & -1 & & & & \\
\hline 1 & & $\frac{7}{47}$ & 40 & 26 & 50 & & & 14 & 5 & 50 & 40 & & \\
\hline & 50 & ${ }_{46}^{47}$ & ${ }_{38}^{37}$ & ${ }_{28}^{25}$ & 50 & & & 10 & $\begin{array}{l}7 \\
5\end{array}$ & 50 & ${ }_{38}^{41}$ & & \\
\hline $\begin{array}{l}3 \\
3\end{array}$ & 50 & 46 & 40 & 28 & 50 & & & 10 & $\begin{array}{r}5 \\
5\end{array}$ & 5 & 38 & 11 & \\
\hline 6 & 50 & 44 & 36 & $\begin{array}{lll}21 \\
25\end{array}$ & 50 & & & 8 & 5 & 50 & 39 & 8 & \\
\hline${ }_{8}^{7}$ & 50 & 44 & 38 & ${ }_{27}^{25}$ & 50 & & & 7 & $\begin{array}{l}4 \\
5\end{array}$ & 50 & 40 & 1. & \\
\hline $\begin{array}{l}9 \\
10\end{array}$ & 50 & 45 & 36 & ${ }_{27}^{24}$ & 50 & & & 15 & 7 & 50 & 35 & 8 & \\
\hline $\begin{array}{l}11 \\
12\end{array}$ & 50 & 46 & 40 & ${ }_{28}^{26}$ & 50 & & & 70 & $\begin{array}{l}4 \\
5\end{array}$ & 50 & 35 & 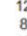 & \\
\hline $\begin{array}{ll}13 \\
14\end{array}$ & 50 & $\begin{array}{l}46 \\
44\end{array}$ & $\begin{array}{l}38 \\
38\end{array}$ & $\begin{array}{l}24 \\
26\end{array}$ & $\begin{array}{l}50 \\
50\end{array}$ & & & $\begin{array}{l}8 \\
80\end{array}$ & $\begin{array}{l}4 \\
7\end{array}$ & $\begin{array}{l}50 \\
50\end{array}$ & $\begin{array}{c}38 \\
39\end{array}$ & 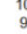 & $\begin{array}{l}4 \\
5 \\
5\end{array}$ \\
\hline $\begin{array}{l}15 \\
16\end{array}$ & $\begin{array}{c}50 \\
50\end{array}$ & $\begin{array}{l}46 \\
44 \\
44\end{array}$ & $\begin{array}{l}36 \\
40 \\
40\end{array}$ & $\begin{array}{l}26 \\
{ }_{28}\end{array}$ & $\begin{array}{c}50 \\
50\end{array}$ & & & 8 & $\begin{array}{l}7 \\
4\end{array}$ & $\begin{array}{l}50 \\
50\end{array}$ & $\begin{array}{l}37 \\
36\end{array}$ & $\begin{array}{l}16 \\
18\end{array}$ & $\begin{array}{l}4 \\
5 \\
5\end{array}$ \\
\hline 18 & $\begin{array}{l}50 \\
50 \\
50\end{array}$ & $\begin{array}{l}48 \\
45 \\
45\end{array}$ & $\begin{array}{l}40 \\
39 \\
39\end{array}$ & $\begin{array}{l}25 \\
{ }_{25}\end{array}$ & $\begin{array}{l}50 \\
50\end{array}$ & & & 8 & $\begin{array}{l}5 \\
5\end{array}$ & $\begin{array}{l}50 \\
50 \\
50\end{array}$ & $\begin{array}{l}40 \\
48 \\
38\end{array}$ & 17 & $\begin{array}{l}7 \\
4\end{array}$ \\
\hline${ }_{20}^{19}$ & $\begin{array}{l}50 \\
50\end{array}$ & $\begin{array}{l}46 \\
46 \\
45\end{array}$ & $\begin{array}{l}39 \\
40 \\
40\end{array}$ & $\begin{array}{l}{ }_{27}^{27} \\
{ }^{2}\end{array}$ & $\begin{array}{l}50 \\
50\end{array}$ & & & 74 & $\begin{array}{l}4 \\
7\end{array}$ & $\begin{array}{l}50 \\
50\end{array}$ & 35 & $\begin{array}{l}7 \\
12\end{array}$ & $\begin{array}{l}4 \\
5\end{array}$ \\
\hline Jumlah & $\frac{1000}{50}$ & 157 & 711 & $\frac{524}{262}$ & $\frac{1000}{50}$ & & & $\frac{01}{0.0}$ & $\begin{array}{l}109 \\
54\end{array}$ & $\frac{1000}{50}$ & $\frac{731}{375}$ & & $\begin{array}{l}\frac{96}{48} \\
48\end{array}$ \\
\hline
\end{tabular}

Nilai organoleptik terendah terdapat pada Tkan yang diberi perlakuan dipukul clengan kayu pada bagian kepala dan ikan yarg mati menggelepar. Berdasarkan nilai tersebut di atas untuk ikan yang dipukul dengan kayu dan mati menggelepar sebaiknya langsung dikonsumsi, agar supaya mutu kesegaran dari ikan masih dapat dirasakan. Yang menyebabkan mutu ikan menurun yaitu cara kematian. Menurut llyas (1983), ikan yang berjuang keras menghabiskan tenaganya untuk mati terbukti lebih cepat busuk dari pada ikan yang cepat mati dengan tenang. Demikian terlihat jelas bahwa ikan yang cepat mati lebih segar dibandingkan ikan yang lama mati.

Nasran (1989) menjelaskan bahwa ada faktor-faktor yang mempengaruhi kesegaran ikan yaitu faktor interen dan faktor eksteren. Faktor interen meliputi jenis ikan, umur, makanan, kematangan gonad, kandungan lemak dan cara kematian ikan. Sedangkan faktor eksteren mencakup kondisi lingkungan seperti suhu, musim, jenis makanan yang tersedia dan perlakuan penanganan pada ikan.

Ikan yang mati menggelepar lama kematian 15-20 menit, untuk ikan yang dipukul dengan kayu pada bagian kepala lama kematian 5-10 menit dan untuk ikan yang disuntik/gancu lama kematian tidak lebih dari 1 menit. Apabila ikan disuntik tidak mengenai otak, maka ikan tidak akan langsung mati tetapi akan terus menggele- 
par hingga mati. Penelitian ini menggunakan ikan kakap dengan ukuran $15-20 \mathrm{~cm}$.

Hasil yang diperoleh ini dan disesuaikan dengan standar organoleptik ikan segar berdasarkan kriteria mutu ikan segar, maka dapat dinyatakan bahwa ikan yang mati dengan perlakuan disuntik/gancu pada bagian otak untuk 0-2 hari termasuk dalam kelas mutu I, hari ke-4 termasuk kelas mutu III dan hari ke-6 termasuk dalam kelas mutu of grade. Untuk ikan yang perlakuan dipukul dengan kayu dan mati menggelepar, 0 hari termasuk dalam kelas mutu I, hari ke-2 termasuk dalam kelas mutu III dan untuk hari ke-4 dan 6 termasuk dalam kelas mutu of grade. Ini berarti kelas mutu I dan III masih dapat diterima secara organoleptik.

$$
\text { Hadiwiyoto (1993) menyatakan }
$$

bahwa parameter fisikawi ikan dapat menentukan kesegaran ikan, yaitu:

1. Kenampakan luar. Ikan yang masih segar mempunyai kenampakan cerah, tidak suram. Keadaan ini terjadi karena belum banyak perubahan biokimia yanig terjadi.

2. Kelenturan daging. Ikan segar dagingnya cukup lentur. Apabila daging ikan dibengkokkan, maka setelah difepas segera akan kembali lagi keg bentuknya semula.

3. Keadaan mata. Parameter ini merupakan yang paling mudah untyk dilihat. Perubahan kesegaran ikan akan menyebabkan perubahan yang nyata pada kecerahan matanya.

4. Keadaan daging. Keadaan daging menentukan'sekali kualitasnya. Ikan yang masih baik kesegarannya, dagingnya kenyal, Jika ditekan dengan jari maka bekasnya akan segera kembali. Pada permukaan tubuhnya belum terdapat lendir yarrg menyebabkan kenampakan ikan menjadi suram atau kusam dan tidak menarik.

5. Keadaan insang dan sisik. Warna insang dapat digunakan sebagai tanda apakah ikan masih keadaan segar atau tidak segar lagi. Pada ikan yang masih segar, warna insangnya masih cerah. Sebaliknya ikan yang sudah tidak segar warna insangnya menjadi coklat gelap. Sisik ikan juga merupakan tanda kesegaran ikan. Jika ikan bersisik, maka pada ikan yang masih segar sisiknya masih melekat kuat. Tidak mudah dilepaskan dari tubuhnya.

\section{Pengujian Nilai-K}

Dalam urutan pengujian nilai-K telah disebutkan mengenai penggunaan ion resin dan keaktifannya. Dihubungkan dengân hal tersebut di atas, maka dilakukan penentuan persentase recovery dari larutan standar onosin dan IMP. Hasil perhitungan íni didasarkan pada spektrofotometer Varians DMS 100s, dapat dilihat pada Tabegl 2.

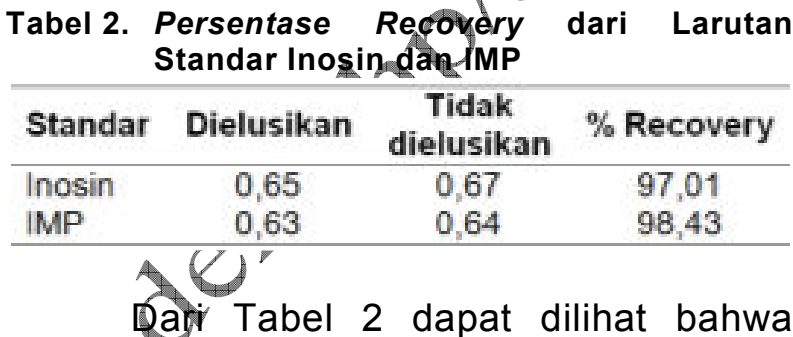
persentase recovery berkisar antara 97,01$98,43 \%$. Hal ini dapat dijadikan standar untuk menyatakan bahwa resin yang digunakan untuk pengujian sampel sudah aktif, sebab menurut Suwetja (1992) bahwa persentase recovery yang baik untuk inosin dan IMP berkisar antara 95-100\%. Ini berarti resin yang telah diaktifkan dapat digunakan pada pengujian sampel.

Nilai-K ikan kakap yang ditangkap di karamba perairan Likupang dapat dilihat pada Tabel 3.

Tabel 3. Nilai-K Sampel Ikan Kakap (Lutjanus sp.) yang Ditangkap di karamba Perairan Likupang

\begin{tabular}{cccc}
\hline \multirow{2}{*}{ Ulangan Nilai-K } \\
\cline { 2 - 4 } & Suntik & Pukul & Menggelepar \\
\hline 1 & 25,83 & 47,52 & 50,00 \\
2 & 25,21 & 50,00 & 50,51 \\
3 & 26,31 & 49,47 & 50,00 \\
\hline Jumlah & 77,35 & 147,99 & 151,03 \\
\hline Rata-rata & 25,78 & 48,99 & 50,34 \\
\hline
\end{tabular}

Dari hasil pengujian rata-rata nilai-K ikan kakap terendah adalah ikan yang diberi perlakuan disuntik/gancu pada bagian otak dengan nilai-K $25,78 \%$, dan tertinggi terdapat pada ikan yang diberi perlakuan dipukul dengan kayu pada bagian kepala $48,99 \%$ dan ikan yang tidak diberi perlakuan atau mati menggelepar $50,34 \%$. Nilai-K yang rendah disebabkan $\mathrm{HxR}$ dan $\mathrm{Hx}$ yang terbentuk hasil peguraian ATP masih dalam 
jumlah yang kecil, untuk nilai-K yang tertinggi, dikarenakan ATP yang ada hampir seluruhnya terurai menjadi $\mathrm{HxR}$ dan $\mathrm{Hx}$.

Menurut Suwetja (1990), bahwa pada ikan yang masih segar nilai-K rendah, sedangkan pada ikan yang tingkat kesegarannya rendah nilai-K akan lebih tinggi. Uchiyama et. al. (1970) dalam Suwetja (1992) menyatakan bahwa nilai-K rata-rata daging ikan segar setelah ikan mati di bawah $5 \%$, nilai-K rata-rata daging ikan di pusat pendaratan $22,5 \%$, nilai-K rata-rata daging ikan untuk sashimi dan sushi sekitar $20 \%$, nilai-K rata-rata daging ikan untuk kamaboko dan surimi 40-60\%.

Nilai-K yang didapat berkisar antara 25,78-50,34\% masih dinyatakan segar dan masih dapat diterima. Karena menurut Suwetja (1990), batas nilai-K untuk ikan sebagai bahan mentah dan untuk beberapa jenis olahan adalah $50 \%$, ini telah dikorelasikan dengan uji organoleptik dan uji TVB. Berdasarkan nilai-K yang diperoleh, maka pengaruh cara kematian ikan yang diberi perlakuan disuntik/gancu pada bagian otak masih lebih baik tingkat kesegarannya, karena pada saat disuntik ikan tersebut langsung mati tidak banyak mengeluarkan energi. Dibandingkan dengan ikan yang diberi perlakuan dipukul pada bagian kepala sampai mati dan dibiarkan mati menggelepar, tingkat kesegarannya lebth rendah dengan nilai-K yang tinggi. Hal ini disebabkan cara kematian ikan tersébut mengalami perjuangan yang berat sehingga energi yang ada dalam tububnya terurai habis.

\section{KESIMPULAN} Dari hasil pengujian ini dapat
disimpulkan:
1.Pengujian secara organoleptik menunjukkan bahwa ikan kakap (Lutjanus sp.) yang diberi perlakuan disuntik pada otak ikan mempunyai nilai yang lebih tinggi dengan daya awet yang lebih lama, dibandingkandengan ikan yang diberi perlakuan dipukul dengan kayu dan mati menggelepar.

2. Tingkat kesegaran ikan kakap yang diambil di perairan likupang yang didasarkan pada nilai-K yaitu $25,78 \%$ untuk perlakuan disuntik/gancu; 48,99\% untuk perlakuan dipukul dengàn kayu pada bagian kepala dan $50.34 \%$ untuk perlakuan menggelepar.

\section{DAFTARPUSTAKA}

Anonimous,. $\frac{1}{1992 .}$ Laporan Tahunan Perikahan Sulawesi Utara 1991. Dinas Perikanar Propinsi Sulawesi Utara.

Hadiwílyoto, S.. 1993. Teknologi Pengolahan Hasil Perikanan. Jilid I. Penerbit Liberty. Yogyakarta.

Hyas, S.. 1983. Teknologi Regrigerasi Hasil Perikanan. Jilid 1 Teknik Pendinginan Ikan. Paripurna. Jakarta.

Nasran, S,. 1989. Masalah Mutu Kesegaran Ikan Tuna dan Difersifikasi Pengolahannya. Makalah Lokakarya Perikanan Tuna. Wartamina

Suwetja, I. K.. 1990. Penentuan Kesegaran Beberapa Jenis Ikan Dengan HPLC. Jurnal Fakultas Perikanan. Vol I No. 3 Hal. 262263. Unsrat. Manado.

1993. Metode Penentuan Mutu Ikan. Penentuan Kesegaran Jilid I. Fakultas Perikanan Unsrat. Manado. 